\title{
EXTERNAL PRESSURE AND LOCAL MOBILIZATION: TRANSNATIONAL ACTIVISM AND THE EMERGENCE OF THE CHINESE LABOR MOVEMENT ${ }^{*}$
}

\author{
Eli Friedman ${ }^{\dagger}$
}

\begin{abstract}
This article elucidates connections between two strategies of transnational social movements-external pressure and local mobilization - and two potential outcomes-paternalism and psychological empowerment. Application of this theoretical framework to the nascent Chinese labor movement indicates that an overreliance on an external-pressure approach results in paternalism, thereby precluding psychological empowerment for aggrieved actors and potentially inhibiting movement growth. Conversely, strategies that relegate external support to a secondary role and privilege local mobilization are more likely to result in psychological empowerment. In this study, I argue that psychological empowerment is a prerequisite for the emergence of a worker-based movement in China. Many studies of cooperation between movement actors from the global North and South have seen this relationship as essentially unproblematic. I begin to problematize the inherent power inequalities between the two sets of actors and will theorize the implications for movement emergence in Southern countries.
\end{abstract}

On September 12, 2005, Disney opened the doors to its long anticipated amusement park on Lantau Island in Hong Kong. However, amid the fanfare was a cacophony of protest that had dogged the corporation for many months prior to the park's opening. Disney had come under attack for everything from misallocation of public money to the presence of shark fin soup on the park's menu. ${ }^{1}$ But the most damning charge leveled against Disney was one that had chased them, wraith-like, around the globe from the United States to France, and now to China. The allegation that workers producing goods for Disney are mistreated, exploited, and disrespected in the workplace has been a public relations nightmare for the company for the past several years, particularly given their image as a purveyor of happiness to children.

That July 1, a date that has been a forum for the airing of all progressive claims against the Hong Kong government, a new contingent of students and academics that were directly targeting the unfair labor practices of the Disney Corporation joined the more typical prodemocracy activists in the streets. These Hong Kong-based activists formed the group Students and Scholars Against Corporate Misbehavior (SACOM), an organization that was established to pressure corporations to improve their human and labor rights conditions, particularly in their China operations. SACOM kicked off the anti-Disney campaign with a series of creative street theater performances. The self-proclaimed "Disney Hunters" set up a mock ticket window (there had recently been a ticket selling bonanza as the park began preselling admission) and passed out "tickets" with information about the abuse of workers producing goods for Disney. Musicians played guitars and sang a parodied version of the immensely popular song "Mice Love Rice" (laoshu ai dami), which mocked the greed of Disney as represented by Mickey Mouse. Other activists made masks, one side portraying the traditional Mickey Mouse face, and the other side a nightmare-inducing evil mouse skull, meant to indicate the hypocrisy of Disney in abusing young factory workers. What made these claims

\footnotetext{
* I thank Jenny Chan, Peter Evans, Tom Gold, Ching Kwan Lee, Kim Voss, Margaret Weir and the Mobilization reviewers for reading and commenting on earlier drafts of this article.

${ }^{\dagger}$ Eli Friedman is a Ph.D. candidate in the Department of Sociology at the University of California, Berkeley. Please direct all correspondence to elidf@berkeley.edu.
} 
perhaps even more powerful than previous indictments of Disney was that the workers being abused were Chinese. Thus, activists were able to frame the issue in a way that called on Hong Kongers to stand in solidarity with their Mainland brothers and sisters.

Approximately six weeks later, a harsh report was released simultaneously by SACOM in Hong Kong and the National Labor Committee (NLC) in New York. ${ }^{2}$ The report (2005) included extensive documentation on the inhumane and exploitative conditions experienced by workers in Disney's supplier factories. Additionally, the report presented evidence that factory managers had been taking steps to deceive factory monitors, people who would visit the factory occasionally to ensure that it was operating in accordance with the company's code of conduct. Disney denied any knowledge of such violations of the law and human rights, and promised to call on the expertise of labor standards auditing firm Verité in investigating the claims. ${ }^{3}$

Let us now consider a very different, yet in many ways parallel, moment in transnational activism. Also in the summer of 2005, workers in Shenzhen's Ronghua ${ }^{4}$ electronics factory walked out on strike. They were fed up with months of unpaid wages and the poor quality of the food in the cafeteria where they took all of their meals. Upon commencement of the strike, management immediately fired the ten people that they had identified as strike leaders, and the workers were forced back onto the production line. However, activists from among the workforce were not satisfied. They consulted with one other and with local nongovernmental organization (NGO) activists on the best course of action for getting the fired workers rehired. They considered going on strike again, petitioning the local labor bureau, and even engaging in civil disobedience at the city government offices.

Although I had concluded fieldwork in Shenzhen before this labor conflict was resolved, some important features were very clear to me. The high degree of organization, ability to coordinate action, and sense of solidarity among the workers in this factory did not emerge out of thin air. Activists from a local labor NGO had been meeting with workers in their dorms for months, establishing dormitory-based discussion groups about conditions in the factory. The NGO activists (almost all of whom were former factory workers), in turn, had been trained in and exposed to organizing techniques from Hong Kong and the West. They had also become familiar with a rights discourse that allowed them to frame the exploitation of migrant workers in a way that resonated with both the workers and third party observers. Most importantly, they had provided the workers with the means for establishing social networks for empowerment. The workers were now able to stand unified and make demands on their employer.

Although these two vignettes are simplifications of the ways in which transnational activism is now occurring, a comparison of them suggests some important distinctions. While the anti-Disney campaign led to extensive coverage in the world's most widely read and respected media outlets, hardly anybody outside of the Ronghua factory knew about the labor conflict there. Though very different in approach, both events sought to accomplish the same goal: the improvement of working conditions for people in China.

This article will draw on current social movement literature as well as field work conducted in China during 2005 and 2006 to argue for a distinction between two approaches to transnational activism: external pressure and local mobilization. In doing so, I hope to elucidate the conditions under which psychological empowerment, as defined by the community psychology literature, is more likely to occur for Chinese factory workers. Also, this will allow me to highlight instances in which a permanently paternalistic relationship between Northern and Southern activists can be avoided. This framework should prove particularly useful in trying to understand transnational activism that involves actors from both the global North and South. In doing so, I will attempt to answer the following questions: In what ways does North-South cooperation in social movements provide both obstacles to and opportunities for the resolution of local grievances? What are some concrete examples of transnational activism, and what is the power differential between Northern and Southern activists? 
Can external pressure create a space for local mobilization and psychological empowerment, or will it necessarily remain paternalistic in nature? To put it another way, how can creative combinations of external pressure and local mobilization be used in order to secure grievance resolution? Finally, what are the implications of external pressure and local mobilization for the emergence of the labor movement in China and social movements in repressive regimes more broadly?

\section{PROBLEMATIZING TRANSNATIONAL ACTIVISM}

A primary objective of this article is to distinguish between two distinct, though not necessarily contradictory, strategies of transnational activism: external pressure and local mobilization. By external pressure, I mean instances in which transnational activists, generally from the global North, take action on behalf of aggrieved individuals or populations, who are generally in the global South. Conversely, local mobilization refers to instances in which aggrieved populations take action on their own behalf to address issues which may be a result of global processes, but are experienced locally. However, my analysis will not stop at sketching these two distinct approaches; rather, I am interested in exploring the link between each strategy and its potential for paternalistic and/or empowering consequences. Paternalism as a consequence of transnational social activism indicates that local actors develop a reliance on outside sympathizers and remain incapable of defending their own rights and interests. If, on the other hand, transnationals play a role in assisting local actors in undergoing psychological empowerment, the possibility for the development of a strong local movement remains a possibility (though certainly not a foregone conclusion).

From a strategic standpoint, empowering local actors for social action grows out of the belief that those being oppressed will always be present at the moment of their oppression, while outsiders may take only a fleeting interest in the cause. Thus, in this article I will theorize the links between two strategies (external pressure and local mobilization) and two consequences of transnational activism (paternalism and psychological empowerment) to explore the implications of these processes for movement emergence. The main thrust of my argument is that an approach to transnational activism that uses external pressure exclusively will lead to paternalism which can inhibit movement formation. Conversely, transnational activism that privileges local mobilization has a greater potential for creating psychological empowerment, a process which is key to the development of class-consciousness and movement emergence. Though it will not be fully explored in this article, repression, especially in an authoritarian political system such as China's, is also a potential outcome of local mobilization. Finally, even if the empirical work presented here is insufficient, I will try to develop a theory of the possibility for productive interaction between external pressure and local mobilization such that locally defined grievances can be redressed.

Making these distinctions is important for several reasons. First, it will cast doubt on the notion that transnational activism is necessarily positive, capable of countering what many see as the fundamentally unjust nature of the current global economy. By complicating the nature of transnational activism, I will suggest that "help" may reinforce Northern and even neoliberal ideological hegemony. Secondly, distinguishing between paternalistic and empowering consequences calls into question the role that Western NGOs and donors play in the building of civil society in nondemocratic nations. Many Western liberal democracies, and especially the United States, have seen the support of NGOs in authoritarian regimes as a primary way to help build democratic consciousness (Wilson 2006). Here, we see that the building of democratic consciousness (to say nothing of institutions) is far from given. Finally, my work will begin to shed some light on forms of transnational activism that $d o$ empower local populations, and can have a greater impact in efforts to check neoliberal globalization. 


\section{THEORIZING TRANSNATIONALISM IN SOCIAL MOVEMENTS}

The pioneers of social movement research focused largely on movements in single nations. These "political process" theorists (McAdam 1982; McAdam, Tarrow, and Tilly 2001; Tarrow 1998) came to be defined by their use of certain core concepts: political opportunity structure (Eisinger 1973; Gamson 1975), framing processes (Snow 1986; Snow and Benford 1988), mobilizing structures ${ }^{5}$ (McAdam, McCarthy, and Zald 1996), and resource mobilization (Zald and McCarthy 1979). ${ }^{6}$ These concepts were largely developed to explain the emergence and dynamics of the American civil rights movement (Andrews 2004; Morris 1984) and then were refined and expanded by scholars focusing on the women's movement (Ferree and Yancey 1995; Ray 1999), the labor movement (Ganz 2000; Voss and Sherman 2000), as well as the environmental and the antinuclear movements (Giugni 2004; Mertig and Dunlap 2001). In the middle to late twentieth century these movements were all primarily contained within a single nation state, and these studies appropriately focused on domestic political and social conditions in their analyses.

The increasingly globalized world of the late twentieth century demanded a reevaluation of the notion that social movements primarily occur within a single country. Increased information flows, faster and more affordable transportation, and the increasing integration of national economies has allowed for, and in many cases demanded, that social movements become transnational. This has led to a growth in face-to-face interactions between Northern and Southern activists to an extent that would have been unthinkable twenty years ago. Social movement scholars have been quick to pick up on this trend, and the past decade has seen a rapid growth in the literature on transnational activism (Brandy and Smith 2005; Florini 2000; Khagram 2004; Khagram, Sikkink, and Riker 2002; Pagnucco 1997; Tarrow 2005) and labor transnationalism (Anner 2003; Kay 2005). While this literature has expanded our knowledge of how globalization has created new targets as well as opportunities for mobilization, few have taken a critical approach in analyzing the dynamics of the role that Northern activists (as well as ideologies and resources) play in the development of social movements in the South (but see Thayer 2001).

One of the first, and still one of the most influential, works on transnational activism is Keck and Sikkink's Activists Beyond Borders: Advocacy Networks in International Politics. The authors' main argument focuses on the emergence of transnational advocacy networks (TANs) and how increasingly international social movements are presenting a challenge to traditional notions about national sovereignty. While it presented some interesting case studies and was important in identifying the increasingly international nature of many social movements, the fact that the book was largely directed at an international relations audience may have prevented the development of a more critical analysis of the implications of these TANs. In a sense, their choice of the word "advocacy" indicates an emphasis on an external pressure approach to activism. "Advocacy" implies that someone (likely an elite from the North) is taking action on behalf of other individuals. Keck and Sikkink's theory of the "boomerang effect" is further evidence of a transnational activism that is not necessarily concerned with local mobilization. The boomerang effect occurs in instances when claimants come up against some barrier to successful resolution of their problem within a domestic context, and then seek help from a third party in a different national setting. This third party then applies pressure, either to the original target of mobilization or to a transnational governance entity (for example, the World Trade Organization, the United Nations, etc.), which can be of assistance in resolving the original grievance. Thus, the boomerang effect necessarily transfers agency from the claimants to cosmopolitan elites that have no direct or personal stake in the matter. While the boomerang effect and TANs probably are an accurate description of how much transnational activism occurs, my work will begin to show that reliance on external pressure without an attempt at local mobilization may render boomerang-style transnationalism ineffective, particularly in authoritarian regimes. Jackie Smith describes how 
transnational mobilizing structures can make the greatest use of local organization and transnational solidarity (as opposed to advocacy):

The advancement of communication and transportation technologies has made more decentralized organizational structures viable. These more decentralized structures, which allow for more intensive, two-way communication within transnational organizations, may contribute to more integrated and democratic participation in TSMOs [Transnational Social Movement Organizations]. (Smith 1997:85)

Of course, the possibility exists for the sorts of democratic, empowering forms of transnational activism that Smith sees here. In fact, there are many cases that have been well documented that show just that. However, we now need to be able to determine under which conditions such democratic organization of transnational social movements is possible, and how mobilized local populations can make effective use of elite Northern allies, without seriously compromising attention to locally defined grievances. In order to do this, it will be important to understand how paternalism operates, why it arises, and what the effects of it are on local populations.

Peter Evans's “counterhegemonic globalization” (2000; 2005) provides us with a good general framework for analyzing North-South relations in transnational social movements. Evans envisions activists using the "infrastructure" that has been created by globalization to counter the injustice that the free-market ideology has wrought on local populations around the globe. However, it is important to note the "counter hegemonic" feature of this theory, as these movements necessarily challenge the dominant ideology and power structures that are underpinning the current historical moment of neoliberal globalization. Cutting through the mist of Northern hegemony that enshrouds the myriad social occurrences in a globalizing society is difficult, but to do so demands not just a critique of the corporations and governments which consciously promote this ideology, but also an awaremess of the ways in which it is unconsciously being recreated, even by those who claim to challenge it. To wit, Evans calls for a dialectic between "strategies that speak to local roots and strategies that leverage global connections" (2005). Thus, while the necessity of securing elite allies and fighting social movements on a global scale is undeniable, one must not forget the people for whom the battle is being waged.

While these macrolevel theories of transnationalism are useful in helping to frame my questions, there have been a select number of case studies that have already hinted at some of the theoretical claims I aim to make. Gregory Maney's (2000) study of the civil rights movement in Northern Ireland was one of the first to recognize potential pitfalls in transnational organizing. In commenting on the lack of local mobilization, Maney says that "weak local capacities resulted in unilateral influence and decision making by INGOs [international NGOs] resulting in a less successful campaign to protect indigenous rights” (2000: 157). Similarly, Thayer (2000) has shown how assistance from the North seriously altered the structure, goals, and organization of the women's movement in Brazil. Thayer describes how the "professionalization" of the movement that was engendered by elite involvement led to a weakening of grassroots input. Here we can see that recruitment of elite allies is not without problems. While internationalizing a movement and seeking supporters beyond the boundaries of the nation state is often useful or even necessary for a successful outcome, one should not assume that this approach is not without certain drawbacks.

Even more relevant to the issue of transnationalism and the building of civil society in China is Luong and Weinthal's work on environmental NGOs in Kazakhstan (1999). The authors begin by making a distinction between Western NGOs (WNGOs) and local NGOs (LNGOs) and their sometimes overlapping, sometimes contradictory interests. Luong and Weinthal first point out that it has become the strategy of many Western liberal democracies, and especially the United States, to promote the development of civil society in nondemocratic societies through the support of LNGOs. As has been the case with the "color 
revolutions" in former Soviet republics, the belief is that these LNGOs can become the foundational building blocks for the construction of a robust, Western-style civil society. However, the authors have found that "the convergence in goals and strategies among environmental LNGOs and WNGOs has inadvertently led to the arrested development of a civil society in Kazakhstan” (1999: 1268). The mechanisms by which this process is occurring in many places in the global South are very clear. First, and perhaps most importantly, is that LNGOs come to depend greatly on material resources from the North. The strategy of this type of social movement organization (SMO) is then shaped by the logic of grant writing, which privileges transnational (read, Northern) discourses at the cost of local grievances. Luong and Weinthal see environmental NGOs pursuing goals of biodiversity and sustainable development, while the goals of environmentally sound development in the Caspian (important locally, but not to funders in Geneva or Washington) have been put on the back burner. What's more, they've seen the activities of these LNGOs gradually shifted away from local organizing and movement building, and towards education and international outreach. This has put these organizations in a position that makes it much more difficult for them to apply pressure on local or national authorities themselves. Instead, they have become dependent on the good will of Western elites to push certain causes on behalf of the Kazakhstani people. Again, we see here the upward transfer of agency from those who are affected to those that are merely working on their behalf. Finally, and most discouragingly, Luong and Weinthal find that "WNGO's funding efforts do not appear to have fostered democracy or other forms of civic activism that could indicate a progression toward building civil society" (2000: 1274). Interestingly enough, this parallels work done on domestic politics by Theda Skocpol in which she argues that recent changes in American civic life have led to a situation in which we have "advocates without members" (1999). While traditional definitions of civil society imply a social realm that is autonomous from the state and can represent the diverse interests of society, in both these cases we see organizations acting independently of both the state and the people. This cannot be seen as constituting the development of civil society or the advancement of democracy.

Both Markus Shulz's work on the Zapatistas (1998) and Steven McKay's study of labor organizing in the Philippines (2006) have provided us with good examples of how creative combinations of external pressure and local mobilization empowers transnational activism. Shulz describes the Intercontinental Encounter for Humanity and Against Neoliberalism, which took place from July 27 to August 3, 1996, when the Zapatistas hosted activists from over forty countries. From the perspective of the Zapatistas, this conference was useful in that it drew international attention to their struggle, and therefore made it more difficult for the Mexican government to violently repress the movement. But what is clear from the outset is that the Zapatistas themselves were in control of the situation, and at no point sacrificed the autonomy of the movement. In a case very similar to my own, McKay demonstrates how valuable transnational connections have been in building a labor movement in the export processing zones of the Philippines. However, this transnationalism must be seen as complementary to, and not a replacement for, local organizing and mobilization.

Work that has been done on the struggle of Mexican maquiladora workers to establish an independent trade union in the Korean-owned Kukdong apparel factory (Hermanson 2004; Ross 2006) has gained widespread notoriety in activist circles for its effective use of both local and international pressure in securing a beneficial outcome. In this case, worker direct action and state repression was followed by an international campaign that involved letter writing to management and Nike (one of Kukdong's primary customers), as well as direct action by American student activists. Through application of pressure on Nike, management, and the Mexican government coming from American trade union and student groups, the workers were eventually successful in establishing an independent trade union. Hermanson (2004: 19) makes clear that "what is different in the Kukdong case ... is that these worker rebellions are beginning to be linked up with national and international support networks, and 
repression and firings are no longer able to easily quash these struggles.” This case is particularly compelling because it uniquely combines worker-initiated local mobilization and external pressure from the United States, which helps reduce local repression by the neoliberal state and eventually helps resolve the original grievance as defined locally.

The benefits of encouraging empowerment of aggrieved local populations have been widely discussed in the community psychology literature, and are readily applicable to social movement theory. Conger and Kanugo (1988) have seen psychological empowerment as a process whereby individuals come to have a feeling of self-efficacy. This can result from a downward delegation of decision making that allows individuals to exercise greater autonomy and self-determination. But a more advanced conception of this process comes from the work of Zimmerman (1990; 1995) and Zimmerman and Rappaport (1988), where empowerment is understood socially, and cognizance of sociopolitical processes is taken into account. For these writers, empowerment is not "person-centered" (Rappaport 1987), but rather should take place at the organizational and community level. ${ }^{8}$ In this conception, understanding of one's sociopolitical context is combined with a sense of control over and efficacy within the community. Through this social process of collective empowerment, communities can come to exert greater democratic control over political institutions. The connection between this sort of empowerment and the emergence of social movements is quite evident.

My research has revealed that a single organization is capable of simultaneously utilizing both external pressure and local mobilization. My primary case, the Guangdong Migrants' Association (GMA, a pseudonym) occupied an intermediary point between the local and the transnational. While portions of their activities were focused on worker training and organizing, they also conducted factory reports for various transnational campaigns such as the anti-Disney campaign. The story of the GMA will reveal the threat that an overreliance on external pressure strategies poses to the building of civil society and the emergence of the labor movement in China.

\section{METHODS AND DESCRIPTION OF THE CASE}

The GMA is an organization that was founded by academics and activists from neighboring Hong Kong who were concerned with increasing reports of mistreatment of factory workers on the Mainland. Funding for the organization comes entirely from Hong Kong and overseas foundations, as domestic sources are essentially nonexistent. While the GMA has a grassroots approach to NGO work and the vast majority of the staff is former factory workers, all three of the on-the-ground administrators are from Hong Kong. Additionally, the board of directors consists exclusively of academics and activists from Hong Kong and their regular meetings are held there. Given that this organization represents a significant point of interaction between Mainland and Hong Kong activists, it is an ideal case for studying the dynamics of transnational activism in the Chinese labor movement.

For the purposes of this article, the Hong Kongers are conceptualized as "Northern" activists, and the Mainlanders as "Southern" activists. People from Hong Kong are certainly not archetypal Northerners: while Hong Kong has one of the most advanced economies in the world, given a particular set of cultural and historical conditions, Hong Kong activists do not leverage the same sort of symbolic power as those from the U.S. and Europe (for example, Euro-Americans have greater symbolic capacity vis-à-vis promotion of a human rights agenda). However, the unique social position of Hong Kong activists allows them to play an important role in the contentious politics of China, and the way that they relate to Mainland activists is reminiscent of more "typical" North-South interactions (Luong and Weinthal 1999; Thayer 2000a). Conceptualized by some as "translators" (Stern 2005; Stern and Merry 2005), these intellectual elites serve as a point of entry for both material and knowledge-based resources into China. Hong Kong activists have been behind the establishment of a great 
number of NGOs on the Mainland, and have also contributed greatly to the dissemination of rights discourse in the People's Republic of China (PRC). Given their ability to speak and write English and their access to elites in the Western NGO, governmental, and corporate world, these activists can be seen as representative of the "transnational" in the context of Mainland China. Thus, we can see the "moment of transnationalism" as being embodied in interactions between Hong Kong and Mainland activists, though American activists will also enter the story.

This article is based on research conducted in 2005 and 2006 in South China's Pearl River Delta. During this time, I participated in three trainings of GMA staff conducted by foreigners, attended one meeting of SACOM, and remained in regular email contact with both organizers and people on the executive board of the GMA. The most concentrated period of research was in July and August of 2005 when I spent an entire month doing an internship at the GMA, during which time I helped translate materials from Chinese to English. At all points in the research, I made my identity as a researcher known, and my internship was arranged by the director of the GMA. In the course of my stay, I participated in most of the major activities of the organization. The major exception was that I did not travel with them to worker dormitories, as the GMA had recently been under intense scrutiny from the authorities, and the presence of a foreigner inside factories might cause problems. I spent the majority of each day in the offices and in the adjoining activity center, where workers and volunteers would gather each evening to read the paper, watch television, and chat about whatever was on their minds. These informal discussions with workers and volunteers were an important data source. In addition to participant observation and informal conversations, I conducted 20 formal, in-depth interviews. Respondents included all of the Hong Kong and Mainland staff of the GMA as well as several of the most active workers and volunteers that were associated with the organization.

Finally, a word on the comparability of the GMA and SACOM is necessary. Given their different structures and locations, these two organizations have different strengths, capacities, goals, and strategies. For an organization such as the GMA with greater proximity (both physical and cultural) to Chinese workers, a local mobilization approach is more viable. On the other hand, SACOM has to deal with a greater distance from the workers it is trying to help, and this of course has an impact on the type of strategies it employs. In this article I am not attempting to explain the variation in goals, strategies, and outcomes between these admittedly very different organizations. Rather, these two cases are meant to exemplify two approaches to transnational activism, and to highlight the respective benefits and shortcomings when it comes to the resolution of worker grievances.

\section{TRANSNATIONALISM AS EXTERNAL PRESSURE}

One of the biggest obstacles to effective local mobilization at the GMA was the decisionmaking process and power structure of the organization. As already mentioned, the executive board consists exclusively of Hong Kong academics and activists, though they frequently seek the advice of other foreign experts and labor activists. These meetings are held in Hong Kong, and visa restrictions make it difficult for the organization's Mainland organizers (to say nothing of the workers) to attend their meetings. Thus, these "frontline" organizers, individuals that are former factory workers and therefore most capable of building meaningful relationships with current workers, have difficulty participating in the high-level decisionmaking process of the organization. Though the on-the-ground Hong Kong administrators as well as the board members will seek input from the Mainlanders, there is no routinized mechanism for Mainlander input.

This fact has had an obvious affect on the morale and organizing capabilities of the staff. Lixue, a Mainland staff member with more than five years experience at the GMA had this to 
say when asked what the biggest problem with the organization was: "I want the leaders to listen to us frontline organizers," and in the most explicit indication of paternalism complained that "[the executive board] treats us like children." She also said the organization needed better "vertical integration," explaining that she felt there was a gap in communication and perception between the decision makers and those on-the-ground. Lixue went on to say that she felt she did not know the direction or goals of the GMA. That one of the organization's most experienced organizers felt like this is strong evidence of a communication gap between top and bottom.

Lack of awareness of the direction of the organization was quite widespread among Mainland staff. In interview after interview, staff members seemed confused, and in many cases were embarrassed that they could not tell me what they thought the purpose of their work was. They were always able to tell me what they thought the direction of the organization should be, but did not know where the organization was actually going. An example from a staff meeting illustrates (in part) the cause of such confusion.

The staff meeting on July 18, 2005, commenced with a discussion of the recent walkout that had occurred at the neighboring Ronghua electronics factory. Given the proximity of the factory to the GMA offices, some officials from the Labor Bureau came by to have a chat with the administrators. Kathy, one of the Hong Kong staff, told everybody that this official had told her, "I'm warning you, you are operating illegally.", The implication was that they might try to shut the organization down, given its semilegal registration status. Concerned, the Hong Kong staff began to talk about how to deal with the authorities if they were approached. Flatly contradicting what the Mainland staff all knew to be true, the director Susan stated categorically that the GMA is not involved in any worker organizing, and that, "we're only conducting programs that workers need."11 Given that Mainland organizers had been involved with workers from the Ronghua factory for quite some time by then, this comment caused great confusion among the staff. A particularly smart, and at times rebellious staff member, Zhoumei, spoke up at this point. She wanted to know what to tell the authorities if they had in fact been organizing a factory. Susan refused to acknowledge this as a possibility, and maintained that the organization does not engage in such work. She concluded by saying that most of the work of the GMA is concerned with "popularizing the law" (pufa) and cut the conversation short.

This interaction illustrates the general lack of transparency that Mainland organizers often complained about. This lack of democratic procedure most noticeably resulted in paternalism in the Disney campaign. As mentioned at the outset, shortly before the opening of Hong Kong Disneyland, a scathing report was released on working conditions in Disney's supplier factories. But this information could not be gathered by Northern elites. The only individuals who had access to this information were the Mainland activists who communicated with migrant workers, and who could ultimately forge the relationships necessary to learn about conditions inside the factory. And yet, none of the Mainlanders understood why they were collecting this information. They had a vague sense that they were going to issue a report that might improve conditions for the workers, but they had absolutely no idea why this approach was being used, as they had had no role in deciding it. Wenya, perhaps the most talented — and certainly the most experienced-organizer at the GMA, commented to me, "You understand more than I do [about the campaign],"12 as she knew that I had met with people in Hong Kong that were spearheading the campaign. Thus, we see a problematic relationship between the elite transnationals and the grassroots activists, with activists being used as a resource without receiving any information as to why a certain strategy is being used. What's more, this was a campaign in which the aggrieved population (the factory workers) was totally unaware that any action was being taken on their behalf, much less why this particular strategy was chosen. Of course, if the end result of the Disney campaign is that conditions in the factory are improved, workers will not be upset. However, we can see here again that agency has been shifted upwards, removed from the individuals that are affected 
and transferred to Northern elites fighting on their behalf. Unless this strategy is combined with on-the-ground organizing, it precludes a moment of "cognitive liberation" (McAdam 1982; 1989) among the workers (to say nothing of empowering communities) and diminishes the potential for local mobilization.

At this point, it may seem as if the primary relationship is between the transnationals and Mainland activists. The charge could be leveled that by leaving the workers out of the story, I am ignoring the relationship that I claim is of the most importance. However, nothing could be further from the truth. The point is that the workers themselves knew even less about the Disney campaign than the Mainland organizers. The organizers were well informed compared to the workers. Conversations with workers about transnational activism yielded no results, as it is a phenomenon with which they were totally unfamiliar. By using the Mainland organizers as a bellwether for the consciousness of the Chinese working class, I am able to gain greater insight into how this process occurs.

Over the next several months, Disney agreed to sit down for four rounds of negotiations with SACOM to address the lists of demands. In their 2005 report, SACOM had pointed out a series of problems in four Disney supplier factories, including serious problems with occupational safety and health, wages paid below minimum wage, excessive working hours, poor living conditions, and falsified information provided to factory inspectors, among others. SACOM, clearly cognizant of the dangers of a paternalistic approach to movement building, included a demand for democratic worker representative bodies in the factories, as well as trainings for the workers. As described to me by members of the Hong Kong group, the hope was that the external pressure could open up some space for worker representation in the factory, something that they correctly recognized as being potentially quite useful in local movement building. Disney was relatively cooperative on issues related to occupational safety and health, and agreed to let some Hong Kong NGOs conduct trainings within the factory. However, they were continually unwilling to accept the demand that the supplier factories establish democratic worker representative bodies. As one member of SACOM lamented, "aside from these [occupational safety and health issues], Disney didn't take a very responsible attitude towards our demands.” 13

After the negotiations and the in-factory trainings, there were some improvements, particularly in one factory that had been suffering an inordinately high number of workplace injuries. After Disney forced the supplier to make some changes in the factory, injuries were reduced quite a lot, and this must clearly be seen as a positive result. However, SACOM was generally disappointed with Disney's responsiveness and with the relatively minor improvements at the four factories. Thus, in 2006 they decided to launch a second phase of the antiDisney campaign, this time choosing to focus on conditions in three other factories in the Pearl River Delta. This time SACOM had the participation of no fewer than six organizations, with four located in the United States, one in France, and one in Austria. After conducting further research on additional factories, they released "A Second Attempt at Looking for Mickey Mouse's Conscience-A Survey of the Working Conditions of Disney's Supplier Factories in China" (2006), which detailed labor rights violations and put forth more demands on Disney. These demands included involving workers in monitoring for compliance with Disney's own corporate code of conduct by "establishing worker representation in the factory" (2006: 24), adherence to Chinese labor law, and increasing order prices and turnover time. As of December 2006, they had no plans to meet with Disney, but were going to try to disseminate information such that "consumers can ask Disney to do the right thing." ${ }^{, 14}$ The chief coordinator of SACOM told me that "ideally" they would be able to push for democratic elections for a worker representative body, but that the focus was going to be on making sure workers had contracts, were aware of Disney's code of conduct, and would have access to some in-factory training.

The failure of the first round of the anti-Disney campaign to establish democratically elected worker representative bodies in the supplier factories demonstrates one of the primary 
pitfalls of an external pressure approach to movement building. SACOM, an organization run by people who genuinely believe in the goal of worker empowerment, had originally selected one of the target factories because the GMA (which works closely with SACOM) had been conducting extensive outreach there. Some of the workers from the factory had volunteered at the GMA, and SACOM believed that the workers had a higher level of consciousness. Thus, it would seem as though this factory held good possibilities for a Kukdong-like combination of external pressure and local mobilization. However, in this case the local mobilization never materialized. The fact that it did not arise should not be surprising; the repressive attitude of the Chinese government toward independent labor organizing makes grassroots worker activism incredibly difficult. Instances in which workers engage in collective action tend to be in response to severe and immediate problems in the workplace (Chen 2000; Lee 2007). What is crucial to see in this case, however, is that SACOM determined that moving ahead with an "external pressure only" approach was viable. This decision had to do with the organization's assessment of the political opportunity structure, in the sense that waiting for the moment when they could effectively coordinate external pressure with local mobilization might mean indefinite inaction. Thus, SACOM moved ahead with an external pressure approach, which, by the organization's own account, had not produced significant victories after a year and a half. While it is impossible to ascribe the lack of success to something that did not happen (that is, lack of local mobilization), it is possible to imagine that pressure from above as well as below may have led to a more favorable outcome.

\section{TRANSNATIONAL ACTIVISM AS LOCAL MOBILIZATION}

How is it possible that workers, living under the rule of a regime that is fundamentally opposed to any form of independent labor organization, are able to stand up and fight for themselves? Proponents of what I would classify as an external pressure approach claim that the authoritarian nature of the Chinese party-state precludes the more radical forms of social action that allow for local mobilization. But the reality of GMA actions challenges this belief.

While many of the GMA's programs would qualify as being focused on creating external pressure, they are also capable of empowering workers in a way few labor NGOs on the Mainland are. In nearly every interview I conducted with GMA staff, they said that the most important work they do is to "raise workers' consciousness," a phrase that implies class formation and cognizance of one's rights and interests. By serving as a conduit for external resources, information, and frames, the Hong Kong activists from the GMA have provided Mainland activists with an opportunity to do the most important work for the building of the labor movement: worker organizing. In assisting workers to establish dormitory- and factorybased networks, the GMA has provided them with the means for local mobilization. Once workers have developed organizing skills and experienced the cognitive liberation that a moment of insurgency often produces, the foundation for the emergence of a movement is in place, something that, almost by definition, cannot occur within a strictly external pressureoriented framework.

Numerous instances of worker psychological empowerment occurred while I was conducting research. One good example involved GMA organizers' involvement in organizing in the Huangxin factory (a pseudonym). One afternoon in early July, Zhou Qingtai, a worker that had recently injured his hand in the factory, sat down and talked with me about conditions in the factory. Mr. Zhou, a young man of about 20 years of age, said that the pay in the factory was not too bad, but it was the benefits that were really the issue. He was particularly upset about the situation with the dormitories. As opposed to the majority of factories in South China's export processing zones, Huangxin only provided housing for 60 percent of the workforce (according to Mr. Zhou), and the other workers were forced to pay extra money to 
find housing in the surrounding area. Given his injury, he was receiving compensation for a few months, and so had time to try to push for some improvements in the factory.

The GMA played a critical role in developing Mr. Zhou as an activist. He stated several times that he had been totally unaware of his legal rights before coming into contact with GMA activists, and that they had given him inspiration to fight back. He was quite militant, and stated, "I'm not afraid [to take action] because the law is on my side." It is this sentiment that the Mainland activists are trying to develop among the workers when they talk about "raising consciousness." The recognition that workers have rights, and that they can fight back when these rights are violated, often arises during the transmission of international human and labor rights discourses. It is, of course, transnational activists that have played the most significant role in importing these discourses and methods of framing issues, and we can thus see how they play a vital role in the formation of migrant worker insurgency. This is not to imply that international involvement is necessary for the development of local activism, but rather to suggest that it can play a conducive role in the process.

Mr. Zhou continued talking about problems in the factory, and how he was going to counter injustices he felt were being committed against him and his fellow workers. He then showed me a lengthy petition that he was planning to circulate before presenting it to the management. The petition demanded improvement in wages, more money for people who work in excessive heat, provision of dorms for all the workers, and perhaps most importantly, the establishment of a union. Mr. Zhou had composed this letter in close consultation with both Hong Kong and Mainland organizers from the GMA. At this point he was thinking of the best strategy for convincing workers to sign the document. At the time, Emma Green, an experienced union organizer from the United States, was visiting the GMA, and she began asking questions to help him think through the best approach to this problem. It was evident that he had never organized anything before, because he believed that he would just go by himself from room to room collecting signatures. Emma quickly pointed out that management would be unlikely to listen to any demands unless a significant portion of the 10,000+ workers in the factory had signed the letter. Mr. Zhou understood, and began asking her about organizing strategies for a petition drive.

Unfortunately, in the fall and winter of 2006, several top organizers left the GMA for personal and political reasons (which are not relevant to my discussion here). However, at least three of these organizers had their consciousness raised to the extent that they were committed to finding a way to continue their grassroots organizing, even if they were not able to do it with the GMA. With support from Hong Kong and other foreign activists, these organizers have managed to piece together enough financial resources from overseas to support themselves and to continue the work they see as most important in advancing the rights and interests of the Chinese working class. In a period of great repression of labor NGOs throughout China, these organizers, with support from foreign activists, have been able to continue to assist workers in standing up against the illegal behavior of exploitative bosses.

One activity that is by no means radical, but which certainly allows workers to take action on their own behalf, is legal consultation. The export processing factories throughout China are rife with legal violations, as management's hubris and the endemic corruption of local officials have often reduced legal codes to a meaningless pile of paper. But with encouragement from the central government's exhortations to construct a society that is ruled by law, aggrieved actors have increasingly been turning to legal proceedings in an attempt to recover back wages, seek compensation for injuries (Lee 2007), or in some cases, to form a branch of the All China Federation of Trade Unions. One day in the winter of 2006, an acquaintance of the organizers brought a friend by to learn about his legal rights. The man had worked in the same factory for eleven years, an exceedingly long term of employment for the region, but had recently been fired. Although he was sure he had been fired unfairly, he said, "We come from the countryside and don't understand the labor law." He had come to seek legal advice from one of the organizers who has extensive knowledge of the labor contract laws in China. 
While I do not know whether this individual was ever rehired or was given a more generous severance package, the intellectual resources provided to him by a foreign-supported group of activists allowed him to try to take action on his own behalf.

Even more impressive than their work with legal advising has been these activists' involvement with the workers at Xingrun textile factory (a pseudonym). The activists began visiting this factory regularly in the summer of 2006, first establishing relationships with the workers, and then giving them some informal training on workers' rights and organizing skills. After only three months of visiting workers in this factory, they claimed that "our trainees' consciousness has noticeably improved," (personal communication) and that three worker-leaders had already emerged. After three months, these three leaders as well as three other activists composed a letter to management asking that they receive at least two days of rest per month, that piece rates be displayed publicly, that holiday pay rates be clarified, and that drinking water dispensers be installed on every floor. These requests were not radical; indeed, the workers were just asking for things to which they were legally entitled. Under their own initiative, and without receiving orders from outside, these activists convinced 28 other workers to sign the letter and then presented it to the boss. After management failed to respond for a full day, these 28 workers, as well as an additional 22, walked off the job. At this point, management became quite nervous and agreed to meet with three worker representatives. Although the boss refused to install drinking water on every floor, he met all three of the other demands, and within a month workers calculated that their wages had increased 100-200 Renminbi a month, even though they were now also receiving two full days of rest. Though foreign activists were key in developing the GMA organizers' consciousness and supplying them with material resources to continue with labor activism, in the end it was the workers themselves who (1) identified the source of injustice, (2) decided when, where, and how to take action, and (3) successfully engaged in social struggle in defense of their own rights and interests. In this case, the Xingrun workers were able to receive external support via the GMA organizers, and yet agency was retained locally, much to the aid of the cause.

The examples of Zhou Qingtai, other activists from Huangxin (Mr. Zhou was not the only Huangxin worker involved in the action), and the Xingrun worker-activists show how transnationals can work to empower locals. The GMA, funded and established by Northern elites, has hired local workers and trained them as organizers. These Mainland organizers, in turn, have recruited what they refer to as "volunteers" (worker-activists) who are then deployed to organize workers to take action for themselves. In these cases we have an instance where the consciousness-raising and organizer-training activities of the GMA and its organizers have left the workers in Huangxin and Xingrun factories in a better position to fight back when they see their rights being violated by an exploitative management. They do not need to wait for the Western companies for which they are producing goods to decide that bad treatment of workers constitutes a threat to their image. They do not need to wait for largely ineffectual ${ }^{15}$ third-party auditors to arrive from the North to slap management on the wrist. And they certainly do not need to wait for consumers in the North to decide that buying sweatshopproduced products is immoral (or unfashionable). Rather, these workers, once equipped with the consciousness and skills necessary to organize themselves, can take action when they deem it necessary. This constitutes empowerment, and transnationals have played a fundamental role in promoting it in the still authoritarian state of the People's Republic.

\section{IMPLICATIONS FOR THEORY AND THE CHINESE LABOR MOVEMENT}

While transnational activism and transnational social movement organizations have come to play an ever-greater role in both local and international social movements, this phenomenon is not without unexpected consequences. Specifically, I see transnational activism in the devel- 
opment of China's labor movement as potentially producing both paternalistic and empowering results. Particularly in an authoritarian regime, external pressure may sometimes be the prerequisite of local mobilization and psychological empowerment, though this has not been true in the cases explored in this article. Though I have focused on developing idealtypical examples of the external-pressure and local-mobilization approaches, the two can coexist in a manner that allows for movement building and successful resolution of local grievances. ${ }^{16}$ My general theory of transnational activism can be schematized as follows:

Figure 1. Schematic of Transnational Activism

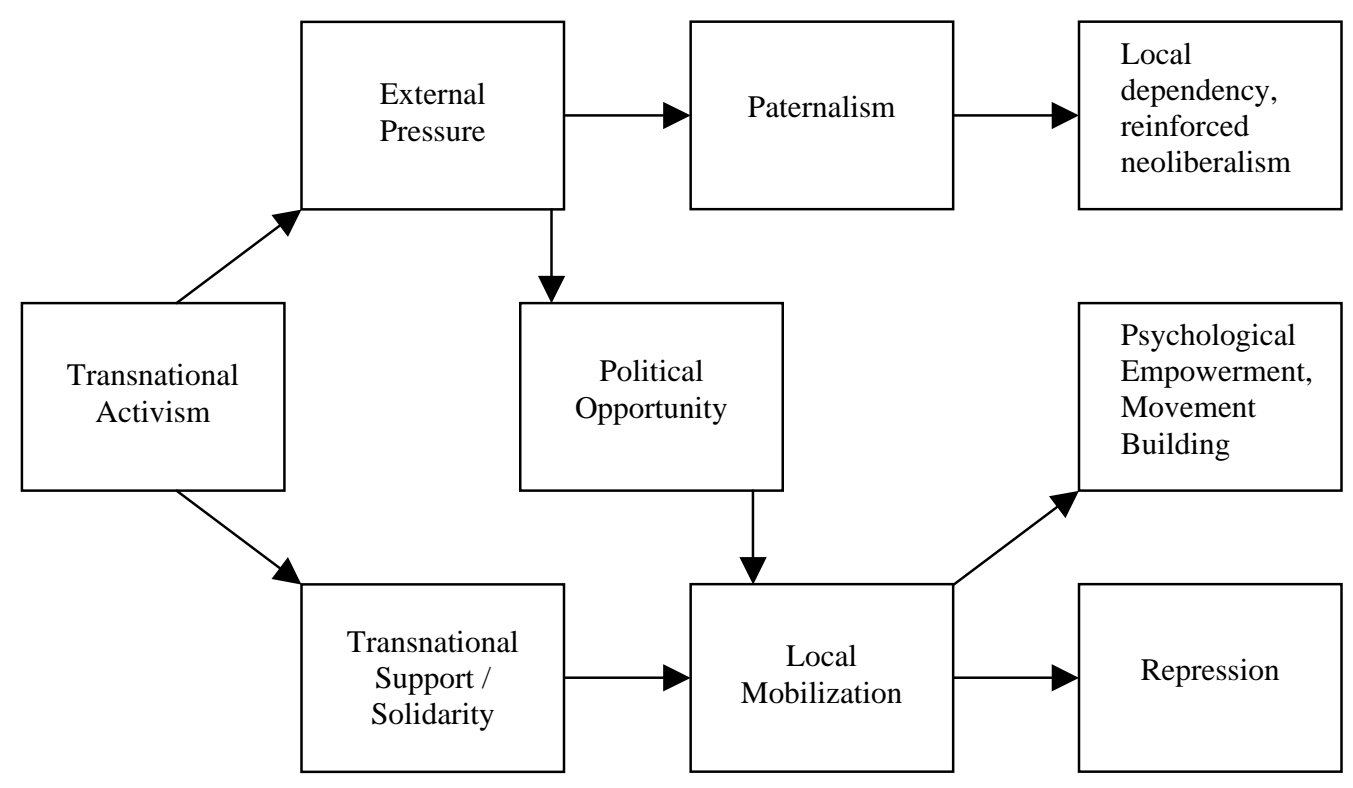

In the above figure we can see that the two primary approaches to transnational activism are external pressure and transnational support for local mobilization. If an external pressure approach is taken, it can result in either (1) paternalism, which results in local dependency and inhibits movement formation; or (2) the production of political opportunities, which can than be exploited if there has been a parallel development in local mobilization (potentially supported by transnational support or solidarity). If actors are taking direct action on their own behalf it can lead to psychological empowerment and movement building or, especially in authoritarian states, government repression. An explanation as to why local mobilization results in repression in some cases and movement building in others is clearly beyond the scope of this article.

This approach to theorizing transnational social movements has some immediate theoretical points that have only recently begun to be considered by scholars. The political process model was largely inattentive to the dynamics between elites and aggrieved actors within the context of nationally based social movements. This blind spot has been transferred to the newer literature on transnational activism, where these sorts of disparities in social position and their implications for movement dynamics are even more salient. My work is in part an attempt to show that the act of advocating on behalf of aggrieved actors (as is the case in Keck and Sikkink's boomerang model) can fundamentally affect strategy formulation and the defining of grievances. This insight can be readily adapted into theory when applied to both domestic and transnational social movements. While some studying the antisweatshop move- 
ment have begun to look at innovative combinations of external pressure and local mobilization, the implications for class-consciousness and movement emergence remain undertheorized. More work needs to be done on determining what sorts of conditions both internal to the movement and in the external political environment make successful combinations of the two approaches more or less likely. Additionally, there is a dearth of good empirical work documenting the tension between paternalism-engendering and political opportunity-creating external pressure. While this article is certainly incapable of fully re-solving these issues, it has been my goal to get them on the table for discussion, and to present some empirical work that speaks to these theoretical points.

Though clearly concerned with theoretical issues, I have also have tried to address some of the practical and concrete political implications of transnationalism. From the perspective of many movement actors, an approach that utilizes external pressure has a definite appeal. First of all, given that labor militancy and the formation of independent trade unions are anathema to the Chinese Communist Party, the "political opportunity structure" ${ }^{17}$ can be interpreted as being largely closed. People who take this position believe that less militant forms of activism are all that is possible right now, and that they can be used to open up more space in the future. Many people that genuinely want to improve the lives of the Chinese working class support an external pressure approach, believing that "something is better than nothing." And secondly, many Northern activists deeply care about the conditions of the Chinese working class and want to be able to help. While these activists are incapable of leading strikes in Chinese factories, they often times have access to networks and channels of influence located externally. Mobilizing these networks in an attempt at defending the interests of Chinese workers is often the most obvious choice for such actors.

From the outset, it is clear that at times external pressure can be a necessary step in arriving at local mobilization. One cannot view social change as being exclusively a bottom up process (Voss and Sherman 2000). Indeed, international pressure from elite third parties has been of incredible importance in many social movements, perhaps the best example of which is the battle against apartheid in South Africa (Klotz 2002). International involvement can be crucial in producing symbolic events which can dramatically alter the course of the movement (Sewell 1996; Sewell and McAdam 2001). These events should not be brushed aside as superficial public relations stunts, as they have the possibility to produce significant structural change. What's more, movement organizing in China is very difficult right now, and social insurgency certainly could endanger the safety or livelihood of Chinese activists. If China can be made to feel isolated in the international community for not adhering to basic standards of human and labor rights, this may have some impact domestically. Finally, if external pressure can in fact improve working conditions in China's factories (and this is an empirical question), this approach should not be dismissed merely on ideological grounds.

That being said, there is little reason to believe that an approach which utilizes external pressure exclusively holds much hope for promoting the Chinese labor movement or a viable counterhegemony. This has to do with the fact that the potential consequence of paternalism inhibits the development of a social movement, as the usurpation of agency by Northern elites renders local actors impotent and ignorant. A movement cannot emerge merely among people who have taken an interest in the issues because of moral concern. Ultimately, elite academics and people from the international NGO world hold very little leverage over those that control the global supply chain — that is, the Chinese government and transnational capital. However, the individuals that are producing the goods hold an incredible amount of latent power.

The process of aggrieved workers taking action on their own behalf has implications not just for individual cases, but also for class formation and movement building. Perhaps first inspired by Marx's theory of class struggle (Tucker 1978), a host of theorists have written on the psychological impacts of participation in collective action and the way in which it can encourage class formation (Thompson 1978). The process of psychological empowerment described earlier finds parallels in the concepts of "cognitive liberation" (McAdam 1982), 
"cultures of solidarity" (Fantasia 1988), or "liminality" (Yang 2000) where scholars have theorized that participation in collective action can produce psychological effects in movement actors that allows for movement consolidation and a desire to continue in social activism. These concepts can be readily integrated into the psychological empowerment framework if we operate under the assumption that there is a dialogical or mutually supporting relationship between individual and community empowerment. With specific regard to workers, Thompson in particular argues that the process of struggle is a necessary precursor to the emergence of class-consciousness (and, we can assume, movement emergence).

To put it bluntly: classes do not exist as separate entities, look around, find an enemy class, and then start to struggle. On the contrary, people find themselves in a society structured in determined ways (crucially, but not exclusively, in productive relations), they experience exploitation (or the need to maintain power over those whom they exploit), they identify points of antagonistic interest, they commence to struggle around these issues and in the process of struggling they discover themselves as classes, they come to know this discovery as class-consciousness. (1978: 149)

Though a post-Maoist workers' class-consciousness is either not yet emerging or is only in a nascent stage of development (Lee 1998; Pun 2005), most scholars would agree that a broad based and coherent labor movement cannot emerge until there is some formulation of a collective identity (Polletta and Jasper 2001). If we are to assume that this process grows out of struggle and contention, then it follows that excessive paternalism may inhibit class and movement formation.

When considering the benefits of external pressure and local mobilization, we must pay attention to both the material and cognitive "residues." As indicated earlier, there is as yet little evidence that either external pressure or local mobilization (in combination or independently of each other) have produced significant material gains for the new Chinese working class. This of course has to do with the market fundamentalism of the regime and local officials' unwillingness to compromise the "investment environment" by increasing production costs. However, when we consider the potential cognitive residues from these distinct approaches, it would seem that local mobilization has much greater potential in bringing about movement emergence. While an exclusive reliance on an external pressure model has the danger of slipping into a paternalism that does nothing to change worker consciousness, local mobilization is quite different. By its very definition, local mobilization demands that workers participate in their own struggle. Thus, even in the event of "defeat" (for example, state repression militates against material improvements), local mobilization has the potential to produce the residue of psychological empowerment, which can serve as the cognitive foundation for movement emergence.

The last point that needs to be reinforced has to do with the relationship between paternalistic outcomes and the project of neoliberalism. A key feature of the utopian neoliberal vision is a vibrant civil society that can fill the social welfare vacuum left by the retreat of the state (Somers 2005), as well as to produce hegemony-engendering legitimating discourses to support the continuation of surplus appropriation (Gramsci 1971). Foundations such as the National Endowment for Democracy, the Ford Foundation, and the Asia Foundation are interested in promoting a civil society that works in harmony with the global expansion of free markets. Once movement organizations become financially dependent on these foundations, goal setting and organizational priorities can very easily be determined by the neoliberal agenda (Bartley 2007). Thus, in the Chinese labor movement we see increasing attention to paternalistic programs such as factory monitoring (a key feature of corporate social responsibility), and provision of legal and health services, while actual organizing and programs that seek to build worker power on the shop floor are given a backseat or are flat out eliminated. This is due in part to the fact that the Chinese state backs up its commitment to capital accumulation with authoritarian politics. However, capital-rich foundations from the 
global North are generally supportive of the neoliberal project; therefore, it is unlikely that they will be willing to fund counterhegemonic movements. An approach that seeks to empower those whose lives are trampled on by the unrestrained free market is the only likely path to genuine counterhegemony.

What, then, can sympathetic elites from the global North do to support the Chinese labor movement? Are we to assume that any involvement will necessarily adversely affect local mobilization? The answer is, of course, an emphatic "No." Though not specifically mentioned earlier, the work of the GMA that resulted in local mobilization was largely funded by a prominent American union. In general, money from progressive Western trade unions is less problematic than foundation money, in that these unions can be genuinely interested in building worker power and an international labor movement. Aside from financial resources, outsiders have been crucial in importing frames and organizing techniques, without which local organizing would be nearly impossible. And finally, external pressure on the government and Western brands does have the potential to create political space. However, if there are no empowered activists or movements to exploit this space, it will be as if the opportunity never even existed.

In the case of China, perhaps the most persuasive argument in favor of strictly adhering to an external pressure approach is that there is nothing else that can be done at present. In this article, I have tried to present some evidence that chips away at this myth. While the cases drawn upon here are far from generalizable and may be outliers as social phenomena, they also show that empowerment is possible. This article has attempted to argue that exclusive reliance on external pressure precludes the development of local mobilization and possibilities for actor empowerment. If social movements are to be effective in achieving the goals of the claimants, attention to local mobilization must always be a consideration when activists from the North partake in Southern social movements.

\section{NOTES}

\footnotetext{
${ }^{1}$ Bradsher, Keith. June 24, 2005. "Shark Soup is off the Menu at Hong Kong Disneyland.” New York Times. Hui, Jessie. June 21, 2005. "Global Protest.” South China Morning Post.

${ }^{2}$ Teather, David. August 20, 2005. "Disney Accused of Labour Abuses in Chinese Factories." Guardian.

${ }^{3}$ Lee, Min. August 19, 2005. "Disney to Investigate Abuse Allegations at China Factories." Associated Press.

${ }^{4}$ Pseudonym

${ }^{5}$ This concept generally refers to social movement organizations. This is problematic in the case of China, given that the authoritarian regime will not allow any civil society organizations with extensive horizontal ties. In China, this concept needs to be stretched somewhat to include things such as work units (Cai 2002) and student dormitories (Zhao 1998; 2001).

${ }^{6}$ For a good explanation of these concepts see Tarrow 1998.

${ }^{7}$ For an analysis of the effect of professionalization of civic engagement in domestic U.S. politics, see Skocpol 1999.

${ }^{8}$ For Zimmerman (1995), “organizational empowerment includes processes and structures that enhance members' skills and provide them with the mutual support necessary to effect community level change," while "at the community level of analysis, empowerment refers to individuals working together in an organized fashion to improve their collective lives and linkages among community organizations and agencies that help maintain that quality of life."

${ }^{9}$ Interview, July 2005

${ }^{10}$ Field notes, July 2005

${ }^{11}$ Field notes, July 2005

${ }^{12}$ Field notes, July 2005

${ }^{13}$ Interview, December 2006

${ }^{14}$ Interview, December 2006

${ }^{15}$ Even the very pro-business magazine Business Week has recently admitted that auditing of Chinese factories has not really improved conditions for workers. See Business Week 2006.

${ }^{16}$ The Kukdong case mentioned earlier is the most widely documented example.

${ }^{17}$ The political opportunity structure (POS), as noted earlier, is one of the central concepts deployed by the political process theorists. The basic argument is that an "open” POS affords activists many chances for movement formation and progression. Repression, a hostile political environment, and counter-movements can all lead to a closing of the POS, which of course makes movement emergence much more difficult or impossible.
} 


\section{REFERENCES}

Andrews, Kenneth T. 2004. Freedom is a Constant Struggle: The Mississippi Civil Rights Movement and its Legacy. Chicago: University of Chicago Press.

Anner, Mark. 2003. "Industrial Structure, the State, and Ideology: Shaping Labor Transnationalism in the Brazilian Auto Industry.” Social Science History 27: 603-34.

Bandy, Joe, and Jackie Smith. 2005. Coalitions Across Borders: Transnational Protest and the Neoliberal Order. New York: Rowman \& Littlefield.

Bartley, Tim. 2007. "How Foundations Shape Social Movements: The Construction of an Organizational Field and the Rise of Forest Certification.” Social Problems 54: 229-55.

Business Week. 2006. “Secrets, Lies, and Sweatshops.” Business Week.

Cai, Yongshun. 2002. "The Resistance of Chinese Laid-off Workers in the Reform Period.” The China Quarterly 170: 327-44.

Chen, Feng. 2000. "Subsistence Crises, Managerial Corruption and Labour Protests in China." The China Journal 44: 41-63.

Conger, Jay A., and Rabindra N. Kanungo. 1988. “The Empowerment Process: Integrating Theory and Practice.” The Academy of Management Review 13: 471-82.

Eisinger, Peter K. 1973. "The Conditions of Protest Behavior in American Cities.” American Political Science Review 67: 11-28.

Evans, Peter. 2000. "Fighting Marginalization with Transnational Networks: Counter-Hegemonic Globalization.” Contemporary Sociology 29: 230-41.

. 2005. "Counter-Hegemonic Globalization: Transnational Social Movements in the Contemporary Global Political Economy.” Pp. 655-668 in Handbook of Political Sociology, edited by Thomas Janoski, Alexander M. Hicks, and Mildred Schwartz. New York: Cambridge University Press.

Fantasia, Rick. 1988. Cultures of Solidarity: Consciousness, Action, and Contemporary American Workers. Berkeley: University of California Press.

Ferree, Myra Marx, and Patricia Martin Yancey. 1995. Feminist Organizations: Harvest of the New Women's Movement. Philadelphia: Temple University Press.

Florini, Ann M. 2000. “The Third Force: The Rise of Transnational Civil Society.” Washington, DC: Carnegie Endowment for International Peace.

Gamson, William. 1975. The Strategy of Social Protest. Homewood, IL: The Dorsey Press.

Ganz, Marhsall. 2000. "Resources and Resourcefulness: Strategic Capacity in the Unionization of California Agriculture, 1959-1966.” American Journal of Sociology 105: 1003-62.

Giugni, Marco. 2004. Social Protest and Policy Change: Ecology, Antinuclear, and Peace Movements in Comparative Perspective. Lanham, MD: Rowman \& Littlefield.

Gramsci, Antonio. 1971. Selections from the Prison Notebooks. New York: International Publishers.

Hermanson, Jeff. 2004. "Global Corporations, Global Campaigns: The Struggle for Justice at Kukdong International in Mexico.” American Center for International Labor Solidarity.

Kay, Tamara. 2005. "Labor Transnationalism and Global Governance: The Impact of NAFTA on Transnational Labor Relationships in North America.” American Journal of Sociology 111: 715-56.

Khagram, Sanjeev. 2004. Dams and Development: Transnational Struggles for Water and Power. Ithaca, NY: Cornell University Press.

Khagram, Sanjeev, Kathryn Sikkink, and James Riker. 2002. Restructuring World Politics: Transnational Social Movements, Networks, and Norms. Minneapolis: University of Minnesota Press.

Klotz, Audie. 2002. "Transnational Activism and Global Transformations: The Anti-Apartheid and Abolitionist Experiences.” European Journal of International Relations 8: 49-76.

Lee, Ching-Kwan. 1998. Gender and the South China Miracle: Two Worlds of Factory Women. Berkeley: University of California Press.

- 2007. Against the Law: Labor Protests in China's Rustbelt and Sunbelt. Berkeley: University of California Press.

Luong, Pauline Jones, and Erika Weinthal. 1999. "The NGO Paradox: Democratic Goals and Nondemocratic Outcomes in Kazakhstan.” Europe-Asia Studies 51: 1267-84.

Maney, Gregory M. 2000. “Transnational Mobilization and Civil Rights in Northern Ireland.” Social Problems 47: 153-179.

Marx, Karl. 1977. Capital: A Critique of Political Economy, vol. 1. New York: Vintage Books.

McAdam, Doug. 1982. Political Process and the Development of Black Insurgency, 1930-1970. Chicago: University of Chicago Press. 
. 1989. “The Biographical Consequences of Activism.” American Sociological Review 54: 744-60.

McAdam, Doug, John D. McCarthy, and Mayer N. Zald. 1996. Comparative Perspectives on Social Movements: Political Opportunities, Mobilizing Structures, and Cultural Framings. New York: Cambridge University Press.

McAdam, Doug, Sidney Tarrow, and Charles Tilly. 2001. Dynamics of Contention. New York: Cambrdige University Press.

McKay, Steven C. 2006. “The Squeaky Wheel’s Dilemma: New Forms of Labor Organizing in the Philippines.” Labor Studies Journal 30: 41-63.

Mertig, Angela, and Riley Dunlap. 2001. "Environmentalism, New Social Movements, and the New Class: A Cross-national Investigation.” Rural Sociology 66: 113-136.

Morris, Aldon. 1984. The Origins of the Civil Rights Movement. New York: The Free Press.

Pagnucco, Ron. 1997. "The Transnational Strategies of the Service for Peace and Justice in Latin America.” Pp. 123-140 in Transnational Social Movements and Global Politics: Solidarity Beyond the State, edited by Jackie Smith, Charles Chatfield, and Ron Pagnucco. Syracuse, NY: Syracuse University Press.

Polletta, Francesca, and James Jasper. 2001. “Collective Identity and Social Movements.” Annual Review of Sociology 27: 283-305.

Pun, Ngai. 2005. Made in China: Women Factory Workers in a Global Workplace. Durham, NC: Duke University Press.

Rappaport, Julian. 1987. "Terms of Empowerment/Exemplars of Prevention: Toward a Theory for Community Psychology.” American Journal of Community Psychology 15: 121-148.

Ray, Raka. 1999. Fields of Protest: Women's Movements in India. Minneapolis: University of Minnesota Pess.

Ross, Robert. 2006. "A Tale of Two Factories: Successful Resistance to Sweatshops and the Limits of Firefighting.” Labor Studies Journal 30: 65-85.

Schulz, Markus S. 1998. "Collective Action Across Borders: Opportunity Structures, Network Capacities, and Communicative Praxis in the Age of Advanced Globalization.” Sociological Perspectives 41: 587-616.

Sewell, William H. 1996. “Three Temporalities: Toward an Eventful Sociology.” Pp. 245-80 in The Historic Turn in the Human Sciences, edited by Terrance J. McDonald. Ann Arbor: University of Michigan Press.

Sewell, William H., and Doug McAdam. 2001. "It's About Time: Temporality in the Study of Social Movements and Revolutions.” Pp.89-125 in Silence and Voice in the Study of Contentious Politics, edited by Ronald R Aminzade, Jack A. Goldstone, Doug McAdam, Elizabeth J. Perry, William H. Sewell Jr., Sidney Tarrow, and Charles Tilly. Cambridge: Cambridge University Press.

Skocpol, Theda. 1999. "Advocates without Members: The Recent Transformation of American Civic Life.” Pp. 461-509 in Civil Engagement in American Democracy, edited by Theda Skocpol and Morris Fiorina. Washington D.C.: Brookings and Russell Sage Foundation.

Smith, Jackie. 1997. “Characteristics of the Modern Transnational Social Movement Sector.” Pp. 42-58 in Transnational Social Movements and Global Politics: Solidarity Beyond the State, edited by Jackie Smith, Charles Chatfield, and Ron Pagnucco. Syracuse, NY: Syracuse University Press.

Snow, David. 1986. "Frame Alignment Processes, Micromobilization, and Movement Participation." American Sociological Review 51: 464-81.

Snow, David A., and Robert D. Benford. 1988. "Ideology, Frame Resonance, and Participant Mobilization.” International Social Movement Research 1: 197-217.

Somers, Margaret. 2005. "Beware Trojan Horses Bearing Social Capital: How Privatization Turned Solidarity into a Bowling Team.” Pp. 233-74 in The Politics of Methods in the Human Sciences: Positivism and Epistemological Others, edited by George Steinmetz. Durham, NC: Duke University Press.

Stern, Rachel. 2005. "Unpacking Adaptation: The Female Inheritance Movement in Hong Kong.” Mobilization: An International Journal 10: 421-39.

Stern, Rachel, and Sally Engle Merry. 2005. "The Female Inheritance Movement in Hong Kong: Theorizing the Local/Global Interface.” Current Anthropology 46: 387-409.

Students and Scholars Against Corporate Misbehavior (SACOM). 2005. "Looking for Mickey Mouse’s Conscience: A Survey of the Working Conditions of Disney's Supplier Factories in China.” SACOM.

— 2006. “A Second Attempt at Looking for Mickey Mouse’s Conscience: A Study of the Working Conditions of Disney’s Supplier Factories in China.” SACOM. 
Tarrow, Sidney. 1998. Power in Movement: Social Movements and Contentious Politics. Cambridge: Cambridge University Press.

. 2005. The New Transnational Activism. Cambridge: Cambridge University Press.

Thayer, Millie. 2000a. "Negotiating the Global: Rural Brazilian Women and Transnational Feminism.” Pp. 158-178 in Rethinking Feminism in the Americas, edited by Debra Castillo. Ithaca, NY: Cornell University Press.

_. 2001. "Transnational Feminism: Reading Joan Scott in the Brazilian Sertao.” Ethnography 2: 243-71.

Thompson, Edward P. 1978. "Eighteenth-Century English Society: Class Struggle Without Class?” Social History 3: 133-165.

Tucker, Robert C. 1978. The Marx-Engels Reader. New York: W.W. Norton \& Company.

Voss, Kim, and Rachel Sherman. 2000. "Breaking the Iron Law of Oligarchy: Union Revitalization in the American Labor Movement.” American Journal of Sociology 106: 303-49.

Wilson, Andrew. 2006. "Ukraine’s Orange Revolution, NGOs and the Role of the West." Cambridge Review of International Affairs 19: 21-32.

Yang, Goubin. 2000. "The Liminal Effects of Social Movements: Red Guards and the Transformation of Identity.” Sociological Forum 15: 379-406.

Zald, Mayer N., and John D. McCarthy. 1979. The Dynamics of Social Movements: Resource Mobilization, Social Control and Tactics. Cambridge, MA: Winthrop Publishers.

Zhao, Dingxin. 1998. "Ecologies of Social Movements: Student Mobilization during the 1989 Prodemocracy Movement in Beijing.” American Journal of Sociology 103: 1493-1529.

- 2001. The Power of Tiananmen: State-Society Relations and the 1989 Beijing Student Movement. Chicago: University of Chicago Press.

Zimmerman, Marc A. 1990. "Taking Aim on Empowerment Research: On the Distinction Between Individual and Psychological Conceptions.” American Journal of Community Psychology 18: 169-77. - 1995. "Psychological Empowerment: Issues and Illustrations." American Journal of Community Psychology 23: 581-599.

Zimmerman, Marc A., and Julian Rappaport. 1988. "Citizen Participation, Perceived Control, and Psychological Empowerment.” American Journal of Community Psychology 16: 725-50. 